\title{
CLINICAL SIGNIFICANCE OF QUANTITATIVE HBS ANTIGEN IN THE PREDICTION OF LIVER FIBROSIS IN PATIENTS WITH CHRONIC HEPATITIS B
}

\author{
Marija Dimzova $^{1}$, Irena Kondova-Topuzovska ${ }^{1}$, Zvonko Milenkovic ${ }^{1}$, Magdalena Gaseva ${ }^{1}$, \\ Viktorija Chaloska-Ivanova $^{2}$, Vladimir Serafimoski ${ }^{3}$, Nikola Orovcanec ${ }^{4}$ \\ ${ }^{1}$ University Clinic for Infectious Diseases and Febrile Conditions, Faculty of Medicine "Ss. Cyril and Methodius", \\ Skopje, Republic of Macedonia \\ ${ }^{2}$ University Clinic of Gastroenterohepatology, Faculty of Medicine, University “Ss. Cyril and Methodius", Skopje, Republic of Macedonia \\ ${ }^{3}$ Macedonian Academy of Sciences and Arts, Skopje, Republic of Macedonia \\ ${ }^{4}$ Institute of Epidemiology and Biostatistics, Faculty of Medicine, University "Ss. Cyril and Methodius", \\ Skopje, Republic of Macedonia
}

Corresponding author: Marija Dimzova, University Clinic for Infectious Diseases and Febrile Conditions, Medical University, University "Ss. Cyril and Methodius", Skopje, Republic of Macedonia 17, Mother Theresa Str, 1000 Skopje, Republic of Macedonia, Tel: + 3897566 83 62, Fax: + 3892 3228224, E-mail:marijadimzova@hotmail.com

\section{ABSTRACT}

The assessment of liver fibrosis in patients with chronic hepatitis B (CHB) is of great importance in evaluating the phases of chronic hepatitis B viral infection, prompt administration of antiviral therapy, prevention of disease progression and late complications of CHB infection. Aim: to investigate the clinical significance of quantitative HBs antigen as a predictor for liver fibrosis in patients with $\mathrm{HBe}$ antigen negative chronic hepatitis B and inactive carriers. Material and Methods: the study included 44 treatment naïve patients with chronic hepatitis $\mathrm{B}$, divided into two groups, $\mathrm{HBeAg}$ negative chronic $\mathrm{HBV}$ infection or inactive carriers (IC) and HBeAg negative chronic hepatitis B patients. All patients underwent laboratory, serologic testing, ultrasound and transient elastography (TE). In both patient groups, quantitative HBs antigen (HBsQ), alanine aminotransferase (ALT), hepatitis B virus deoxyribonucleic acid (HBV DNA) and liver fibrosis were analyzed. Results: The value of $\mathrm{HBsQ}$ is significantly higher in patients with HBeAg negative CHB $2477.02 \pm 4535.44 \mathrm{IU} / \mathrm{ml}$ than in the IC group $8791 \pm 11891 \mathrm{IU} / \mathrm{ml} ; \mathrm{Z}=3.32, \mathrm{p}<0.001$ $(\mathrm{p}=0.0009)$. In IC patients, $1(4.76 \%)$ had fibrosis and $20(95.24 \%))$ did not have fibrosis. Out of 23 patients with HBeAg negative chronic hepatitis B, 8 (34.78\%) had fibrosis and 15 (65.22\%) did not have fibrosis. Patients with $\mathrm{HBeAg}$ negative hepatitis B had significantly higher liver fibrosis than IC; Fisher Exact Test $\mathrm{p}<0.05(\mathrm{p}=0.02)$. The increase of HBsQ for one single unit $(\mathrm{IU} / \mathrm{ml})$ does not have predictive value for fibrosis (Ext (B) $=1.00), 95 \%$ C.I. for EXP (B): 1.00-1.00 / p >0.05. Conclusion: Quantitative hepatitis B surface antigen has intermediate weak statistically insignificant prediction for liver fibrosis $R=0.25(\mathrm{p}<0.10)$.

Keywords: chronic hepatitis B, quantitative HBsAg, HBe antigen, HBV DNA

\section{INTRODUCTION}

Hepatitis B viral infection can be manifested as an acute hepatitis, chronic hepatitis, cirrhosis and hepatocellular carcinoma (HCC). [1] The presence of hepatitis B surface antigen (HBsAg) in the serum of the patients for more than six months is a hallmark of chronic hepatitis
$B$ viral infection (CHB), and it is estimated that there are more than 350 million of people with chronic hepatitis $\mathrm{B}$ infection worldwide. $[2,3]$ The sequels of CHB are significant and appear in approximately $5 \%$ of infected adult patients which cause 0.5 to 1.2 billion deaths annually. 
Timely discovery of liver fibrosis is of great importance for starting antiviral therapy on time and preventing the late complications of $\mathrm{CHB}$. The golden standard for the assessment of liver fibrosis is liver biopsy, invasive and expensive procedure with possible serious complications. At the same time, the accurate evaluation of fibrosis by liver biopsy is questionable having in mind the possible sampling error, as well as possible inter and intra-observational discrepancies [4]. Transient elastography (TE) is a surrogate marker for liver biopsy in many studies and is an accurate, fast and easy to perform technique. [5] Quantitative HBsAg (HBsQ) is one of the main serologic markers of interest in chronic HBV viral infection, [6] and represents a non-invasive marker for monitoring both disease progression and prognosis as well as response to antiviral therapy. [7, 8, and 9] Several studies have observed the correlation between quantitative HBsAg and liver fibrosis. [10]

The aim of this study is to determine the clinical significance of quantitative $\mathrm{HBsAg}$ in predicting liver fibrosis.

\section{MATERIAL AND METHODS}

The study was conducted at the University Clinic for Infectious Diseases and Febrile Conditions, Skopje and as a prospective study of treatment naïve patients with serologically confirmed chronic hepatitis B viral infections. The patients were diagnosed and controlled at the outpatient clinic for hepatitis. The inclusion criteria were: age over 18 years, patients with signed informed consent, and patients with serologically confirmed hepatitis B surface antigen (HBsAg) in a period of at least ix months, patients who have been observed in at least two occasions, with a minimum period of follow-up of at least 6 months. The exclusion criteria were: co-infection with human immunodeficiency virus (HIV), hepatitis A(HAV) and hepatitis $\mathrm{C}(\mathrm{HCV})$ as well as other liver diseases with confirmed different ethology. Patients who had received antiviral therapy, patients who are currently on antiviral therapy, patients with hepatocellular carcinoma (HCC) and patients with decompensated liver disease were also not included in the study. The study included 44 patients, 21 in the group of inactive carriers (IC) defined with the presence of HBsAg in patients' serum for more than 6 months, persistently normal level of alanine aminotransferase (ALT) $<40$ IU/ $\mathrm{ml}$ and HBV DNA $<2000 \mathrm{IU} / \mathrm{ml}$ and 23 patients with $\mathrm{HBe} A g$ negative chronic hepatitis $\mathrm{B}$, defined with $\mathrm{HBsAg}$ positivity for more than 6 months, patients who are $\mathrm{HBeAg}$ negative, with ALT levels higher than upper reference limit or normal $(\geq 40$ $\mathrm{IU} / \mathrm{ml}$ ) and HBV DNA > $2000 \mathrm{IU} / \mathrm{ml}$. All patients underwent laboratory and serology testing, as well as quantification of HBV DNA by real time PCR (RT-PCR). Abdominal ultrasound as well as TE was performed on all patients. Relevant clinical variables were age, gender, ALT, hepatitis Be antigen, HBV DNA, HBsAg and fibroscan. The serum level of HBsAg (HBsQ) was quantified with Architect HBsAg assay (Abbott Laboratories) according to the manufacturers' protocol. The detection value varies from 0.05 to $250 \mathrm{IU} /$ ml. Sera with HBsAg level higher than $250 \mathrm{IU} /$ $\mathrm{ml}$ were diluted 1:500. The value of ALT, HBsQ and HBV DNA are expressed in IU/ml. The liver stiffness is measured with transient elastography (TE); fibroscan (EchoSensR, Paris, France) and expressed in kilopascals $(\mathrm{kPa})$, by median value from 10 performed measures, with success rate more than $60 \%$ and interquartile range (IQR) $<0.25$. Both groups of patients, IC and $\mathrm{HBeAg}$ negative $\mathrm{CHB}$ were analyzed for age, gender, ALT, HBsQ, HBV DNA and liver fibrosis.

\section{Statistical analysis}

All data were processed using a statistical computer program Statistica 7.1 for Windows and SPSS Statistics 17.0, where the following statistical tests were used: the differences between both groups of patients with attributive parameters were tested with the use of the Pearson Chi-square test, the Fisher Exact Test (p). For determining the risk of fibrosis, Odds Ratio/RR was used. Descriptive statistics (Mean; Std. Deviation; $\pm 95.00 \%$ CI; Minimum; Maximum) for description of the numerical variables, frequencies and percentages for description of the categorical variables was used. Distribution of the data was tested with the Kolmogorov-Smirnov test; Lilliefors test; Shapiro-Wilks test (p). For testing the difference between the two groups, the analyzed parameters were tested with t-test for independent parameters $(\mathrm{t} / \mathrm{p})$, Mann-Whitney U test $(\mathrm{Z} / \mathrm{p})$. Correlations between HBsQ \& HBV DNA; HBsQ \& ALT were done with the use of Spearman Rank Order (R); and Multiple Regression (R) analysis was performed to find the correlation between dependent and independent variables. In order to identify the predictive values for age, gender, ALT, HBsQ, 
HBV DNA for fibrosis logistic regression analysis (Wald, Exp (B), 95.0\% CI for Exp (B), and p) was used. For all analyzes the p value $<0.05$ was considered statistically significant.

\section{RESULTS}

The study included 44 patients, divided into two groups: 21 patient inactive carriers of hepatitis B (IC) and 23 patients with $\mathrm{HBeAg}$-negative chronic hepatitis B. In the group of IC, $13(61.90 \%)$ were male, and $8(38.10 \%)$ female. The age of the patients varies in the interval of $35.24 \pm 9.32$ years; \pm 95.00 CI: $30.99-39.48$; the minimal age is 19 and the maximum is 56 years. The value of ALT varies in the interval $22.00 \pm 14.65 \mathrm{IU} / \mathrm{ml}$, HBsQ in the interval $2477.02 \pm 4535.44 \mathrm{IU} / \mathrm{ml}$, and HBV DNA varies in the interval $739.14 \pm 606.50 \mathrm{IU} /$ $\mathrm{ml}$. Fibrosis as a form of liver injury measured by (TE) (fibroscan-EchoSenseR), showed that 20 patients $(95.24 \%)$ had no fibrosis, and only 1 (4.76\%) had fibrosis. Correlation between quantitative $\mathrm{HBs}$ antigen (HBsQ) and quantitative $\mathrm{HBV}$ DNA, $(\mathrm{R}=0.45, \mathrm{p}<0.05)$ showed intermediate strong positive significant correlation, while there is very weak positive but statistically insignificant

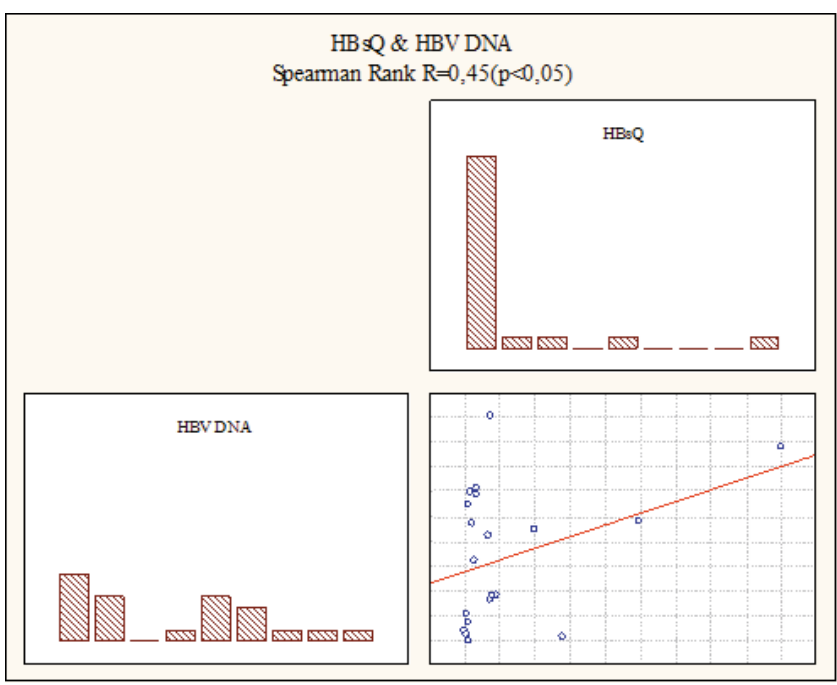

age is 74 years. The value of ALT varies in the interval $57 \pm 53 \mathrm{IU} / \mathrm{ml}, \mathrm{HBsQ}$ varies in the interval $8791 \pm 11891 \mathrm{IU} / \mathrm{ml}$, and quantitative HBV DNA varies in the interval $1222630 \pm 3051050 \mathrm{IU} / \mathrm{ml}$. In the HBeAg negative CHB group, 15 (65.22\%) did not have fibrosis and $8(34.78 \%)$ had fibrosis. From the patients with fibrosis, 3 (13.04\%) had fibrosis F2/F3, 3 (13.04\%) fibrosis F4, 1(4.35\%) with fibrosis F3, and 1 with fibrosis F1/F2. The correlation between HBsQ and HBV DNA showed intermediate weak positive statistically insignificant correlation for $\mathrm{R}=0.31$ and $\mathrm{p}>0.05$ while the correlation between HBsQ and ALT $(\mathrm{R}=0.37, \mathrm{p}>0.05)$ shows intermediate strong positive correlation (Figure 2). In this study, we made a comparison of the values of analyzed parameters between both patients' study groups. There is no significant difference in the distribution for gender Pearson Chi-square $=0.73$ and $p>0.05 \quad(p=0.39)$. Patients with $\mathrm{HBeAg}$ negative $\mathrm{CHB}$ are significantly older than patients IC $(\mathrm{t}=2.43, \mathrm{p}<0.05)$ $(p=0.02)$. Regarding the values of ALT, patients with $\mathrm{HBeAg-negative} \mathrm{CHB}$ have significantly higher ALT than IC $(Z=2.89, p<0.01)(p=0.004)$. $\mathrm{HBsQ}$ in patients with $\mathrm{HBeAg}$-negative chronic hepatitis $B$ for $Z=3.32, p<0.001(p=0.0009)$ is significantly higher than patients IC. HBV DNA is also higher in patients with $\mathrm{HBe} A g$-negative $\mathrm{CHB}$

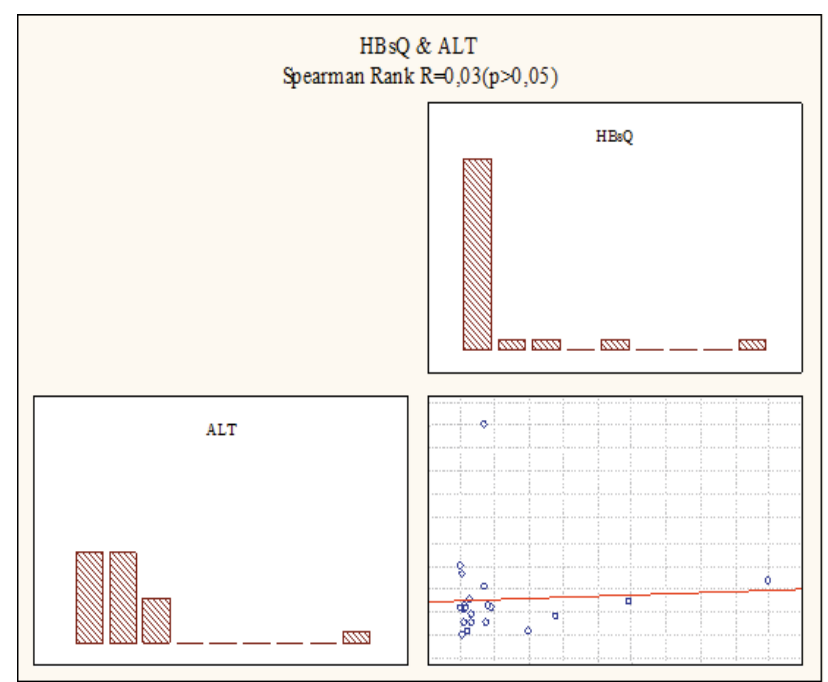

Figure 1. Correlations of $H B S Q / H B V D N A$ and $H B s Q / A L T$ in patients inactive carriers

Abbreviations: HBsQ-quantitative hepatitis B antigen; HBV DNA- hepatitis B virus deoxyribonucleic acid; ALT- alanine aminotransferase

correlation between HBsQ and ALT $(\mathrm{R}=0.03$, $\mathrm{p}>0.05$ ) (Figure 1). In the HBeAg-negative CHB patients out of 23 patients, $17(73.91 \%)$ were male, and $6(26.09 \%)$ female. The patients' age varies in the interval $43.09 \pm 11.80$ years; \pm 95.00 CI: 37.99 48.19 ; the minimal age is 22 , and the maximum
$(\mathrm{Z}=5.67, \mathrm{p}<0.001)(\mathrm{p}=0.000)$ compared to the IC group (Table 1). Fibrosis as a manifestation of liver injury measured with TE, is significantly higher in patients with $\mathrm{HBeAg}$-negative $\mathrm{CHB}$ than in the IC group for Fisher Exact Test $p<0.05(p=0.02)$. In $\mathrm{HBeAg}$-negative CHB group from 23 patients, 


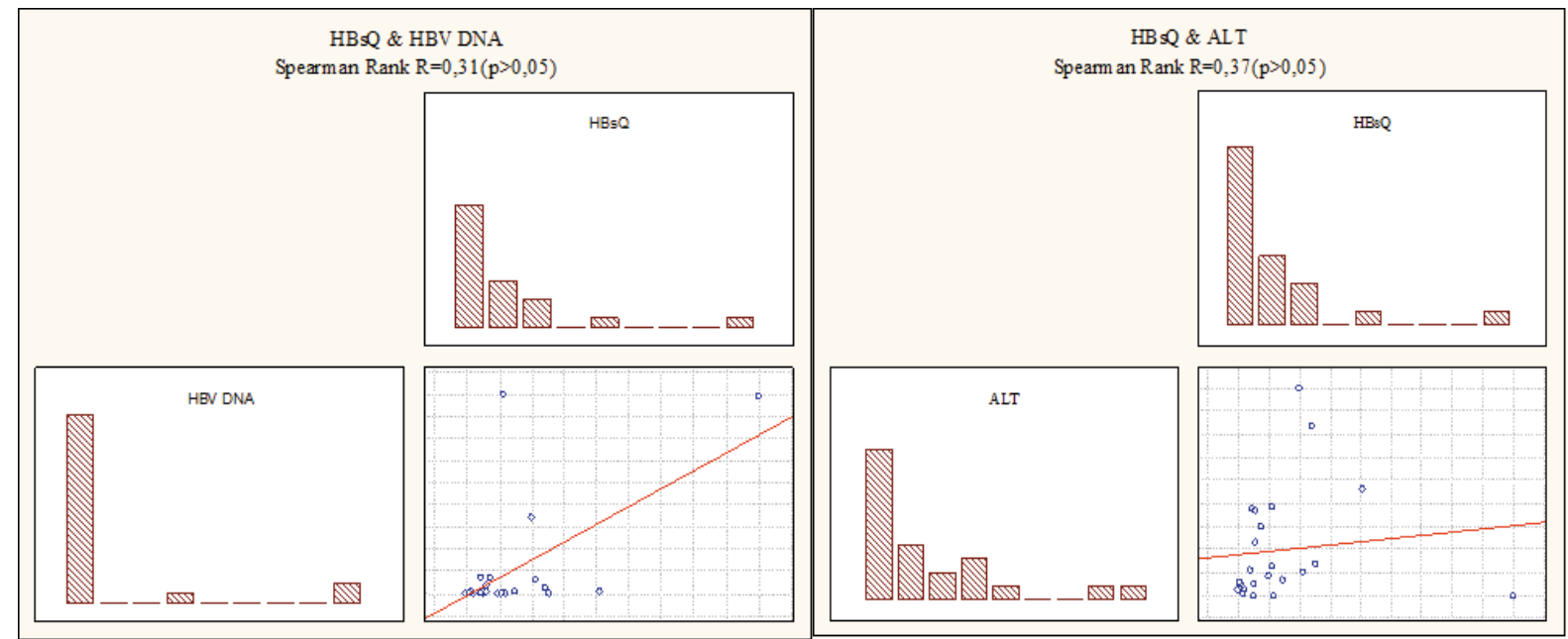

Figure 2. Correlations of $H B S Q / H B V D N A$ and $H B s Q / A L T$ in patients with HBeAg-negative chronic hepatitis $B$

Abbreviations: HBsQ-quantitative hepatitis B antigen; HBV DNA- hepatitis B virus deoxyribonucleic acid; ALT- alanine aminotransferase,

Table 1. Differences between patients IC and HBeAg-negative patients in terms of $A L T / H B s Q / H B V D N A$

\begin{tabular}{|c|c|c|c|c|c|c|c|}
\hline parameter & $\begin{array}{c}\text { Rank Sum } \\
\text { HBeAg }(-)\end{array}$ & $\begin{array}{c}\text { Rank Sum } \\
\text { IC }\end{array}$ & U & Z & p-level & N & N \\
HBeAg $(-)$ & IC \\
\hline ALT & 640,50 & 349,50 & 118,50 & 2,89 & 0,004 & 23 & 21 \\
\hline HBsQ & 659,00 & 331,00 & 100,00 & 3,32 & 0,0009 & 23 & 21 \\
\hline HBV DNA & 759,00 & 231,00 & 0,00 & 5,67 & 0,000 & 23 & 21 \\
\hline
\end{tabular}

Abbreviations: ALT- alanine aminotransferase; HBsQ-quantitative hepatitis B antigen; HBV DNA- hepatitis B virus deoxyribonucleic acid; $\mathrm{HBeAg}(-)$-hepatitis Be antigen negative hepatitis; IC-inactive carriers

$8(34.78 \%)$ had fibrosis and $15(65.22 \%)$ did not. In the IC group, out of 21 patients, $1(4.76 \%)$ was with fibrosis, and $20(95.24 \%)$ did not have fibrosis. Patients with $\mathrm{HBeAg-negative} \mathrm{chronic}$ hepatitis B have 10.67 times greater risk for fibrosis than patients IC; Odds Ratio $=10.67(95 \%$ CI: $1.20-94,74)$ inverse $(0.09)$. For $\mathrm{RR}=7.3(95 \%$ CI:0.995-53.59) the risk for fibrosis in $\mathrm{HBeAg}$ negative chronic hepatitis B group is 7.3 times insignificantly higher than in the IC group. Defining the predictive values for fibrosis in terms of gender, age, ALT, HBsQ, HBV DNA the model for fibrosis showed that the biggest importance is the patient's age (Wald $=6.51 / \mathrm{p}<0.05(\mathrm{p}=0.01)$, HBsQ (Wald $=0.74 / \mathrm{p}>0.05(\mathrm{p}=0.39)$, then the gender (Wald $=0.63 / p>0.05(p=0.43)$, HBV DNA (Wald $=0.19 / p>0.05(p=0.66)$, and the weakest predictability has ALT (Wald $=0.02 / \mathrm{p}>0.05$ $(p=0.90)$ (Table 2). With the increase of patients' age by 1 year, there is a significant increase in the probability for fibrosis by $18.00 \%$ (Ext (B) $=1.18) ; 95 \%$ C.I. for $\operatorname{EXP}(\mathrm{B}): 1.04-1.33 / \mathrm{p}<0.05$. The increase of HBsQ for one single unit (IU/ml) doesn't have predictive value for fibrosis (Ext (B) $=1.00$ ), $95 \%$ C.I. for EXP (B): $1.00-1.00 / \mathrm{p}>0.05$. Female patients compared to male patients have 0.37 times lesser risk for fibrosis (Ext $(B)=0.37)$, 95\% C.I. for EXP (B): $0.03-4.33 / p>0.05$. The increase of HBV DNA for one single unit (IU/ $\mathrm{ml}$ ) has no predictive value for fibrosis (Ext (B) $=1.00), 95 \%$ C.I. for $\operatorname{EXP}(B): 1.00-1.00 / p>0.05$. The increase of ALT for $1 \mathrm{IU} / \mathrm{ml}$ increases the probability for fibrosis for $0.1 \%($ Ext $(B)=1,001)$ insignificantly for $95 \%$ C.I. for EXP (B): 0.98$1.02 / p>0.05$. The area under the ROC curve is 0.883 , which means that in $88.30 \%$ of all possible pairs of patients where one patient has fibrosis and the other does not have fibrosis, this model will 
Table 2. Prediction of liver fibrosis-gender gender, age, $A L T, H B s Q, H B V D N A$

\begin{tabular}{|c|c|c|c|c|c|c|c|c|c|}
\hline & & \multirow[b]{2}{*}{ B } & \multirow[b]{2}{*}{ S.E. } & \multirow[b]{2}{*}{ Wald } & \multirow[b]{2}{*}{ df } & \multirow[b]{2}{*}{ Sig. } & \multirow[b]{2}{*}{$\operatorname{Exp}[\mathbf{B}]$} & \multicolumn{2}{|c|}{$95 \%$ C.I.for $\operatorname{EXP}[B]$} \\
\hline & & & & & & & & Lower & Upper \\
\hline \multirow[t]{6}{*}{ Step $1^{3}$} & Gender [1] & -99 & 1,26 & ,63 & 1 & ,43 & ,37 &, 03 & 4,33 \\
\hline & Age & 16 & ,06 & 6,51 & 1 & ,01 & 1,18 & 1,04 & 1,33 \\
\hline & ALT & ,001 & ,01 &, 02 & 1 & ,90 & 1,001 & 98 & 1,02 \\
\hline & HBsQ &, 000 &,$\infty 0$ &, 74 & 1 & ,39 & 1,00 & 1,00 & 1,00 \\
\hline & HBV DNA &, 000 & , & 19 & 1 & ,66 & 1,00 & 1,00 & 1,00 \\
\hline & Constant & $-8,66$ & 2,98 & 8,42 & 1 & ,004 & ,000 & & \\
\hline \multicolumn{10}{|c|}{ Regression Summary for Dependent Variable: Fibrosis $R=0,25 ; F[1,42]=2,88 ; p<0,097$} \\
\hline & & Beta & & of Beta & & & std. Err. of B & $\mathrm{t}[42]$ & $p$-level \\
\hline Intercept & & & & & & 0,14 & 0,07 & 2,02 & 0,05 \\
\hline HBsQ & & 0,25 & & 0,15 & & , 00001 & 0,00 & 1,70 & 0,10 \\
\hline
\end{tabular}

a. Variable* s) entered on step1: gender, age, ALT, HBsQ, HBV DNA

Abbreviations: ALT- alanine aminotransferase; HBsQ-quantitative hepatitis B antigen; HBV DNA- hepatitis B virus deoxyribonucleic acid; HBeAg (-)-hepatitis Be antigen negative hepatitis; IC-inactive carriers; Std.Err-standard error; CI confidence interval.

determine higher probability for fibrosis. The correlation between fibrosis as a dependable variable and $\mathrm{HBsQ}$ as an independent parameter showed intermediate weak insignificant correlation for $\mathrm{R}=0.25(\mathrm{p}<0.10)$. Namely, the increase of HBsQ for one single unit (IU/ml), increases fibrosis insignificantly for 0.00001 units $(\mathrm{p}>0.05)$.

\section{DISCUSSION}

HBsAg represents a significant prognostic marker in means of disease outcome, not only in the natural history, but also during the antiviral treatment of chronic HBV infection. [9,11]. Many studies showed that the level of HBsAg (HBsQ) can correlate with the serum level of HBV DNA and at the same time is a surrogate marker of intrahepatic covalently closed circular DNA (cccDNA), which is responsible for virus persistence and is a template for viral rep- lication which can vary in different phases of HBV infection. [12,13] Quantification of HBsAg gives us different, but complementary information which can help the physician in the evaluation of different phases of chronic HBV infection and disease progression. Chronic HBV infection is characterized with five different phases [14]: 1.HBeAg-positive chronic HBV infection, former initial immune tolerant phase; 2. HBeAg-positive chronic hepatitis B, former immune active phase; 3. HBeAg-negative chronic HBV infection, former inactive carrier state; 4. HBeAg-negative chronic hepatitis B phase and 5. HBsAg-negative phase. These phases are of great importance in means of clinical approach to the patient, the necessity to perform liver biopsy and decision making for initiating antiviral therapy, but it is not always easy to distinguish between these different phases. Distinguishing $\mathrm{HBeAg-negative} \mathrm{CHB}$ phase from inactive carrier state is of great importance and not that easy due to their similar 
laboratory, biochemical and serological profile. This emphasizes the need for including specific, non-invasive diagnostic serologic markers which would both represent liver injury, but at the same time would also be specific and sensitive markers for determining the phases of the chronic HBV infection. Determining liver fibrosis is crucial in management of patients with $\mathrm{CHB}$, and with the introduction of transient elastography as a non-invasive method, an immense simplification in determining liver fibrosis has been made. In the study of Seto it is found that $\mathrm{HBsQ} \geq 25000 \mathrm{IU} / \mathrm{ml}$ can predict fibrosis with great certainty but in $\mathrm{HBeAg}$ positive patients, while this relation is not so certain in patients with $\mathrm{HBeAg}$-negative $\mathrm{CHB}$ [15]. Our study showed that there is intermediate weak insignificant correlation between $\mathrm{HBs}$ and liver fibrosis in patients with $\mathrm{HBeAg}$-negative $\mathrm{CHB}$. Our study did not include patients with $\mathrm{HBeAg}$ positive CHB. The greatest prediction for liver fibrosis has patients' age (Wald $=6.51 / \mathrm{p}<0.05$ $(p=0.01)$, HBsQ (Wald $=0.74 / p>0.05(p=0.39)$, then gender $($ Wald $=0.63 / p>0.05(p=0.43), H B V$ DNA (Wald $=0.19 / \mathrm{p}>0.05 \quad(\mathrm{p}=0.66)$, and ALT has the slightest influence. In our study, we made comparison in both groups of patients the $\mathrm{HBe} A g-n e g a t i v e ~ \mathrm{CHB}$ group and the inactive carrier group which showed that the value of $\mathrm{HBsQ}$ in patients with $\mathrm{HBeAg}$-negative CHB is higher than in the IC group $(Z=3.32$, $p<0.001)(p=0.0009)$ as well as the value of HBV DNA $(Z=5.67, p<0.001)(p=0.000)$. The study of Zhu [16] carried out over 124 patients with chronic hepatitis B showed that there is correlation between HBV DNA and serum level of $\mathrm{HBsQ}$ in patients with $\mathrm{CHB}$ and at the same time this study showed that the level of HBsQ can appropriately reflect the level of HBV DNA replication. Pearson's correlation analysis showed that the serum level of HBV DNA is positively correlated with the serum level of quantitative HBsQ $(r=0.657, p=0.000<0.05)$. In our study we found that in the group of IC there is intermediate strong positive correlation between HBsQ and HBV DNA, Spearman Rank $\mathrm{R}=0.45(\mathrm{p}<0.05)$, while in the HBeAg-negative group there is intermediate weak positive statically insignificant correlation Spearman Rank $\mathrm{R}=0.31$ and $\mathrm{p}>0.05$. In the study of Balkan [17] 204 patients with chronic hepatitis B were investigated, IC and patients with chronic active hepatitis $\mathrm{B}$, and the correlation between HBsQ and HBV DNA, ALT level, liver fibrosis and HAI index was investigated. No correlation was found in the inactive carrier group, but intermediate positive correlation was found in the patients with chronic $\mathrm{HBeAg}$ positive hepatitis B [17]. Unlike the Balkan's study, our study did not investigate the correlation between quantitative HBsAg and serum HBV DNA in patients with chronic $\mathrm{HBeAg}$ positive hepatitis $\mathrm{B}$, but we found intermediate positive correlation between the investigated parameters in patients with $\mathrm{HBeAg-negative} \mathrm{chronic} \mathrm{hepatitis} \mathrm{B}$, and not in the inactive carrier group. Fibrosis as a form of liver injury is significantly higher in patients with $\mathrm{HBeAg}$-negative chronic hepatitis B compared to IC for Fisher Exact Test $p<0.05$ $(p=0.02)$. At the same time, patients with HBeAg-negative chronic hepatitis B have 10.67 times greater risk for fibrosis than IC for OR = 10.67 (95\% CI: $1.20-94.74)$. There is intermediate weak statistically insignificant correlation between fibrosis as a dependent incidence and $\mathrm{HBsQ}$ as an independent parameter for $\mathrm{R}=0.25$ $(p<0.10)$. Each increase of HBsQ for one single unit $(\mathrm{IU} / \mathrm{ml})$ increases fibrosis insignificantly for 0.00001 units $(p>0.05)$ unlike the study of Hong [18] where there is significant correlation. The Hong study showed that there is intermediate strong positive statistically significant correlation between $\mathrm{HBsQ}$ and quantitative HBV DNA in the IC group of patients $(\mathrm{R}=0.45$, $\mathrm{p}<0.05$ ), while in patients with $\mathrm{HBeAg}$ negative CHB there is intermediate weak positive statistically insignificant correlation $(\mathrm{R}=0.31$, $\mathrm{p}>0.05$ ). In the study of Gunal [19] 99 patients with $\mathrm{HBeAg-negative} \mathrm{chronic} \mathrm{hepatitis} \mathrm{B} \mathrm{were}$ investigated and ALT levels were compared in patients IC and patients with $\mathrm{HBeAg}$-negative chronic hepatitis B, where ALT levels were $25.94 \pm 13.06 \mathrm{IU} / \mathrm{ml}$, and $55.54 \pm 82.38 \mathrm{IU} / \mathrm{ml} \mathrm{re}-$ spectively, showing statistical significance $(\mathrm{p}=$ 0.015 ). This study also showed weak but statistically significant correlation between the level of HBsQ and the ALT level $(\mathrm{r}=0.283, \mathrm{p}=0.005)$. In patients included in our study, ALT level varies in the interval of $22.00 \pm 14.65 \mathrm{IU} / \mathrm{ml}$ in the inactive carrier group, while in patients with HBeAg-negative chronic hepatitis B, the ALT level varies in the interval od $57 \pm 53 \mathrm{IU} / \mathrm{ml}$. The value of ALT is significantly higher in the latter group of patients $(Z=2.89, p<0.01)(p=0.004)$. Similarly to the study of Gunal, our study also showed that there is intermediate strong positive correlation between HBsQ and the ALT level in patients with $\mathrm{HBeAg-negative} \mathrm{chron-}$ 
ic hepatitis $B \mathrm{R}=0.37(\mathrm{p}>0.05)$, while in the IC group there is weak positive statistically insignificant correlation between HBsQ and ALT for $\mathrm{R}=0.03$ and $\mathrm{p}>0.05$. In the study of Liu [20] it has been found that the level of $\mathrm{HBsAg}<1000$ $\mathrm{IU} / \mathrm{mL}$ and HBV DNA $<2000 \mathrm{IU} / \mathrm{mL}$ measured in one point of time give the possibility for determining which patients will stay inactive carriers of hepatitis B with moderate degree of accuracy and they can also predict occurrence of liver cirrhosis, HCC and seroconversion of HBs antigen.

\section{CONCLUSIONS}

Transient elastography represents a fast, simple, safe and painless method for determining liver fibrosis. Fibrosis as a form of liver injury is significantly more present in patients with $\mathrm{HBeAg}$-negative chronic hepatitis B compared to inactive carriers. The investigated relationship between fibrosis as a dependent occurrence and $\mathrm{HBs}$ as an independent parameter showed intermediate weak statistically insignificant correlation. Patients' age and gender had greater influence on fibrosis occurrence. It is important to take all above mentioned variables in determining the risk for fibrosis in both groups of patients. Our study showed that there is intermediate strong positive correlation between HBsQ and HBV DNA in both groups of patients. It is thought that $\mathrm{HBs} Q$ reflects serum replication of hepatitis B virus (HBV DNA). Determining the correlation between $\mathrm{HBsQ}$, HBV DNA, correlation of ALT with HBsQ and HBV DNA, HBsQ and liver injury might ensure more precise evaluation of the risk for liver fibrosis in patients with $\mathrm{HBeAg-negative}$ chronic hepatitis $\mathrm{B}$ and inactive carriers. The evaluation of correlation between HBsQ, HBV DNA and liver injury will also enable proper patient selection, candidates for antiviral treatment for chronic hepatitis B. At the same time, quantification of HBsAg alone, will also define its prognostic value in both disease outcome and treatment. In this way, besides more precise distinction of phases of chronic HBV infection and discriminating patients true inactive carries of hepatitis B virus, quantification of $\mathrm{HBsAg}$ can serve as a serologic marker for evaluating treatment outcome as well.

\section{REFERENCES}

1. Kao JH, Chen DS. "Global control of hepatitis B virus infection”. Lancet Infect Dis. 2002; 2: 395.

2. http://www.who.int/mediacenter/factsheets/ fs204/en/

3. Lavanchy D. "Hepatitis B virus epidemiology, disease burden, treatment, and current and emerging prevention and control measures." J. Viral Hepat. 2004; 11: 97-107.

4. Bedossa P, Carrat F."Liver biopsy: the best, not the gold standard. J Hepatol. 2009; 50: 1-3.

5. Xu X, Su Y, Song R et all: "Performance of transient elastography assessing fibrosis of single hepatitis B infection: A systematic review and meta-analysis of a diagnostic test." Hepatol Int. 2015; 9: 558-66

6. Gheorghița V. et al."Quantitative serum HBsAg in chronic hepatitis B." Therapeutics,Pharmacology and Clinical Toxicology. 2012; 16 (3): 155162.

7. LiawYF. "Clinical Utility of Hepatitis B surface Antigen Quantitation in Patients with Chronic Hepatitis B: A Review.” Hepatology. 2011; 53: 2121-2129.

8. Chevaliez S: "Is HBsAg quantification ready for prime time?" Clin Res Hepatolo Gastroenterol. 2013; 37: 559-63.

9. Loggi E, Vitale G., Conti F., Bernardi M. "Chronic hepatitis B: Are we close to a cure?" Digestive and Liver Disease. 2015; 47: 836-841.

10. Martinot-PeginouxM et al.: HBsAg quantification to predict natural history and treatment outcome in chronic hepatitis B patients. Clin Liver Dis. 2013, 17: 399-412.

11. Samant H, Joshi Aet al. "Correlation of QuantitativeHBsAg with Quantitative HBV DNA in Different Phases of Chronic Hepatitis B (CHB) Patients."J Liver Res Disord Ther. 2016; 1(3).

12. Thompson AJ, Nguyen T, Iser D, et al. "Serum hepatitis B surface antigen and hepatitis B e antigen titers: disease phase influences correlation with viral load and intrahepatic hepatitis B virus markers." Hepatology. 2010; 51: 1933-1944.

13. Brunetto MR. "A new role for an old marker, HBsAg." J Hepatol. 2010; 52: 475-477.

14. European Association for the Study of the Liver. EASL clinical practice guidelines: "Management of chronic hepatitis B virus infection." J Hepatol. 2017; 67: 370-398.

15. Seto WK, Wong DK et al. "High hepatitis B surface antigen levels predict insignigicant fibrosis 
in hepatitis $\mathrm{B}$ e antigen positive chronic hepatitis B." PLoS One. 2012; 7: e43087

16. Zhu HY, Zhang XS. "Relationship between HBV DNA load and levels of serum HBsAg in patients with chronic hepatitis B." European Review for Medical and Pharmacological Sciences. 2016; 20: 2061-2064.

17. Balkan A., Namiduru M.et al. "Are Serum Quantitavie Hepatitis B surface Antigen Levels, Liver Histopathology and Viral Loads related in Chronic Hepatitis B-Infected Patients?" Saudi J Gastronterol. 2016; 22(3) 208-214.
18. Hong MZ, Huagn WQ et al. "Enhanced HBsAg synthesis correlates with increased severity of fibrosis in chronic hepatitis B patients." PLoS One. 2014; 9: 1:e87344.

19. Günal et al. "Relation between serum quantitative HBsAg, ALT and HBV DNAlevels in HBeAg negative chronic HBV infection." Turk J Gastroenterol. 2014; 25: 142-6.

20. Liu J, Yang H, Lee M.,2 Jen C,1 Utermann R., Lu S.et all. "Serum Levels of Hepatitis B SurfaceAntigen and DNA Can Predict Inactive Carriers With Low Risk of Disease Progression." Hepatology. 2016; 64: 381-389.

\title{
Резиме
}

\section{КЛИНИЧКОТО ЗНАЧЕЫЕ НА КВАНТИТАТИВНИОТ НВS АНТИГЕН ВО ПРЕДИКЦИЈА НА ХЕПАТАЛНАТА ФИБРОЗА КАЈ ПАЦИЕНТИ СО ХРОНИЧЕН ХЕПАТИТИС Б}

\author{
Марија Димзова ${ }^{1}$, Ирена Кондова-Топузовска ${ }^{1},{ }^{3 в о н к о ~ М и л е н к о в и к ́ ~}{ }^{1}$, Магдалена Гашева ${ }^{1}$, \\ Викторија Чалоска-Иванова ${ }^{2}$, Владимир Серафимоски ${ }^{3}$, Никола Оровчанец ${ }^{4}$ \\ ${ }^{1}$ Универзитетска клиника за инфективни болести и фебрилни состојби, Медицински факултет, \\ Универзитет „Св. Кирил и Методиј“, Скопје, Република Македонија \\ ${ }^{2}$ Универзитетска клиника за гастроентерохепатологија, Медицински факултет, \\ Универзитет „Св. Кирил и Методиј“, Скопје, Република Македонија \\ ${ }^{3}$ Македонската академија на науките и уметностите, Скопје, Република Македонија \\ ${ }^{4}$ Институт за епидемиологија и биостатистика, Медицински факултет, \\ Универзитет „Св. Кирил и Методиј“, Скопје, Република Македонија
}

Вовед: Проценката за присуство на хепатална фиброза кај пациентите со хроничен хепатитис Б (ХХБ) е од големо значење во евалуација на фазите на хроничната ХБВ инфекција, навремена адиминистрација на антивирусна терапија и превенција на прогресијата на болеста и појава на касните компликации на ХХБ.

Цел: да се определи клиничкото значење на квантитативниот ХБс антиген како предиктор на хепаталната фиброза кај пациенти со ХБеАг негативен хроничен хепатитис и пациентите инактивни носители.

Материјал и методи: Цо студијата беа вклучени 44 пациенти со хроничен хепатитис Б, поделени во две групи, инактивни носители и пациенти со ХБеАг негативен хроничен хепатитис Б. Кај сите пациенти беше спроведено лабораториско и серолошко тестирање, ехосонографија и транзиентна еластрографија (ТЕ). И кај двете групи на пациенти беа анализирани квантитативниот ХБс антиген (HBsQ), аланин аминотрансфераза (АЛТ), хепатитис Б вирусната деоксирибонуклеинска киселина (ХБВ ДНК) и хепаталната фиброза.

Резултати: Вредноста на HBsQ е значајно повисока кај пациентите со ХБеАг негативен хроничен хепатитис Б2477,02 $\pm 4535,44$ во однос на инактивните носители $8791 \pm 11891 \mathrm{IU} / \mathrm{ml} ; Z=3,32$, $\mathrm{p}<0,001$ ( $\mathrm{p}=0,0009)$. Кај ИН, 1 пациент $(4,76 \%)$ имал фиброза, а $20(95,24 \%)$ немале фиброза. Од 23 пациенти со ХБеАг негативен ХХБ 8 (34,78\%) имале фиброза, а $15(65,22 \%)$ немале фиброза. Пациентите со ХБеАг негативен хроничен хепатитис Б имале значајно поголема хепатална фиброза во однос на ИН; Fisher Exact Test $p<0,05$ ( $\mathrm{p}=0,02)$. Зголемувањето на HBsQ за единечна мерка (IU/ $\mathrm{ml})$ нема предиктивна вредност за фиброза (Ext $(\mathrm{B})=1,00), 95 \%$ C.I. for $\operatorname{EXP}(\mathrm{B}): 1.00-1.00$ / p >0, 05.

Заклучок: Квантитативниот ХБс антиген има статистички умерено слаба предикција за хепатална фиброза $\mathrm{R}=0,25(\mathrm{p}<0,10)$.

Клучни зборови: хроничен хепатитис Б, квантитативен ХБс антиген, ХБе антиген. 